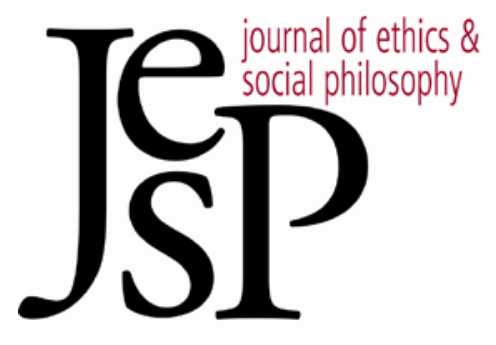

\title{
The State's Duty to Engure Children Are Loved
}

BY LUARA FERRACIOLI

JOURNAL OF ETHICS \& SOCIAL PHILOSOPHY

Vol. 8, No. 2 | September 2014 URL: WWW.JESP.ORG COPYRIGHT (C) LUARA FERRACIOLI 2014 


\title{
The State's Duty to Ensure Children Are Loved
}

\author{
Luara Ferracioli
}

\section{$I^{2}$} N A RECENT AND UNPRECEDENTED DECISION, the Brazilian Supreme Tribunal of Justice condemned a father to pay $\mathrm{R} \$ 200,000$ (the equivalent of $\$ 87,000$ U.S.) to his adult daughter for the moral damages that followed from his lack of affection toward her in childhood. The chief complaint of the daughter, Luciane Souza, was that her father, who separated from her mother when she was still young, did not treat her with affection and did not provide her with the same opportunities he later provided to the children of his second marriage (although he did provide her with child support). ${ }^{1}$ The Tribunal of Justice agreed, and found that the father defaulted on a stringent duty to show warm affection and concern for his daughter, which made him liable for indemnification. ${ }^{2}$ In this case, the Tribunal of Justice seems to be recognizing a moral right on behalf of children to be loved by their parents, and a corresponding duty on behalf of parents to love their children. But do children really have such a right, and do parents have such a duty? ${ }^{3}$ In this essay, I argue that children do have such a right, but that the primary duty bearer is the state and not the child's parents.

This question has recently been addressed in the philosophical literature on children's rights. ${ }^{4}$ There, the claim that children have a right to be loved has been met with two general kinds of skeptical response. 5 According to the first kind of skeptical response, the interest that a child has in being loved is not sufficient to ground a right to be loved. ${ }^{6}$ The thought is that children can have their basic needs met without being loved, so there is no corresponding right to be loved. While this line of

\footnotetext{
1 When explaining why she took her father to court, Luciane Souza said: "I sought his affection in childhood, in adolescence. I sought it when I got married. When my child was born, I came across him in a restaurant and I introduced him to my baby, asking if he wanted to hold him. I said: 'We still have time ...' But he refused." My translation from Portuguese, Folha de São Paulo, May 5, 2012.

2 Folha de São Paulo, May 3, 2012.

3 Throughout this essay, I will use the concept of a parent to refer to the child's primary guardian, who may or may not be biologically related to the child. I will use the word carer to refer to those who care for children in institutional settings, such as schools and orphanages.

${ }^{4}$ S. M. Liao (2006) "The Right of Children to Be Loved," The Journal of Political Philosophy 14(4): 420-40; S. M Liao (2012) "Why Children Need to Be Loved," Critical Review of International Social and Political Philosophy 15(3): 347-58; M. Cowden (2012) "What's Love Got to Do with It? Why a Child Does Not Have a Right to Be Loved," Critical Review of International Social and Political Philosophy 15(3): 325-45; M. Cowden (2012) "A Need Is Not a Right," Critical Review of International Social and Political Philosophy 15(3): 359-62; S. M. Liao (forthcoming) The Right to Be Loved, New York: Oxford University Press.

5 There are also other kinds of skeptic, like those who think that rights talk is misguided, or that children cannot be right-holders. For the purposes of this essay, I assume that rights exist, that they protect interests of sufficient importance to impose correlative duties on others and that children can be right-holders.

"Cowden (2012) "What's Love Got to Do with It?"
} 
response has some merits, it overlooks an important role that love plays in the lives of children. I argue that, once we properly recognize the role that love plays in the lives of children, we will see that it is sufficiently important to ground a right of the child to be loved.

According to the second kind of skeptical response, children cannot have a right to be loved because there can be no corresponding duty to love on the part of parents. This kind of skeptic argues that, since one can have a duty to do something only if it is under one's voluntary control, and love is not typically under one's voluntary control, there cannot be a duty to love on the part of parents. ${ }^{8}$ Indeed, philosophers and nonphilosophers alike seem to agree that, whatever love is, it largely consists of nonvoluntary psychological dispositions. I argue that this response relies on too narrow an understanding of how a right can give rise to duties. While it may well be true that no individual person can have a duty to love, the child's right to be loved can ground a stringent duty on the part of the state to create the conditions for children to be loved.

The discussion to follow will be structured in five parts. In section 1, I engage with the recent philosophical literature on the question of whether children have a moral or human right to be loved. I focus on S. Matthew Liao's defense of this right on the grounds that, all else being equal, children who are loved fare better than children who are not. While I endorse Liao's conclusion, I remain agnostic about the truth of the empirical claims he employs in support of his conclusion. I then move on to defend an alternative account. In particular, I argue that we can ground the right of children to be loved by appealing to the role that love plays in motivating parents to assist their children in the pursuit of the good. The discussion then proceeds as follows. In section 2 , I argue that love can motivate action that goes beyond what morality requires, and that this has implications for how much cost loving parents are likely to bear in order to benefit their children. In section 3, I clarify what I mean by the good life and explain the role of meaning in securing the good life. In section 4, I argue that children, like adults, have a deep interest in finding meaning in their lives. I then defend the claim that loving relationships play two important roles in the meaning of children's lives. On the one hand, since children are not yet in a position to pursue the good on their own, it is important to be in a relationship in which someone else cares deeply about their good, and this is what a loving relationship is. On the other hand, a loving relationship itself forms a large part

\footnotetext{
7 It has also been argued that scholars should focus instead on "establishing moral and philosophical grounding for rights that are currently given little attention by adults and the State - such as a child's economic rights and to fair political representation - rather than confusing rights with love," in ibid.: 343. While it should be acknowledged that the right to be loved, if there is such a right, might not be among the most pressing of rights of children, it is still important to establish whether children do have such a right. The Brazilian Supreme Tribunal of Justice clearly thought that Luciane Souza had such a right.

${ }^{8}$ Kant famously makes this point in The Metaphysics of Morals (1996/1797) M. Gregor, trans., Cambridge: Cambridge University Press, p. 161. See also ibid.
} 
of the meaning of a child's life. It is the role that love plays in securing these two aspects of meaning in a child's life that grounds the right of children to be loved. Finally, in section 5, I explore the question of whether the child's right to be loved corresponds to a duty that can be feasibly discharged. I argue that the duty falls primarily on the state, which in turn will have significant implications for social policy in the areas of adoption, parenting and procreation.

\section{Love and Well-Being}

S. Matthew Liao has recently provided an account of why children have a right to be loved. In his account, children have a right to be loved because human beings have a right to things that are essential for a good life. And love, most notably parental love, is "a primary essential condition for children to have a good life." His conclusion that love is essential in childhood relies on empirical studies showing that children who are not loved, but only adequately cared for, become ill more frequently, have deteriorated learning capacities, become decreasingly attentive to their environment, and fail to thrive physically, emotionally and cognitively. ${ }^{10}$ And because children have a right to be loved, parents, carers and the state must at the very least create the conditions for the emotion of love to arise.

On the face of it, it seems that Liao has succeeded in defending one of the most controversial rights that applies only to children.11 The problem is that he relies too heavily on empirical studies, which makes his conclusion that children have a human right to be loved vulnerable to the accuracy of these studies. Whether Liao is correct in suggesting that the poor indicators mentioned above prove that children need love very much depends on whether these indicators were caused by a lack of love proper, or by a lack of adequate treatment, which can be easily provided by those who do not love the child. Liao thinks that it is the lack of love qua emotion that is doing the work in those cases, and that even if parents pretend to love their children, they will not succeed in discharging their moral obligation. As he puts it, "one can typically pretend to love a child for only a short period of time. At some point, a child will realize that he is not receiving real love." 12 The upshot of Liao's account is that receiving adequate care, and being the object of someone's loving emotion, are both necessary conditions for children to lead good lives.

The empirical underpinnings of Liao's account have recently been challenged. Mhairi Cowden has examined in detail the psychological liter-

\footnotetext{
${ }_{9}$ Liao (2006): 425.

10 Ibid.: 423.

${ }^{11}$ In the literature, these are known as C-rights. C-rights are rights that only children have and that decrease in strength as children become more autonomous. See J. Feinberg (2003) “A Child's Right to an Open Future," Journal of Social Philosophy 34: 124-28. See also N. MacCormick (1976) "Children's Rights: A Test Case for Theories of Right," Archiv für Rechts und Sozialphilosophie 67: 305.

12 Liao (2006): 429.
} 
ature employed in Liao's essay, and has suggested that what really impacts negatively on the well-being of an infant is the sort of treatment she is subjected to, not whether she is the recipient of an emotion. Cowden's careful examination of the empirical literature suggests that what brings about poor health, deteriorated physical, emotional and cognitive capacities, and so on, is the child's loss of contact with an adult she had already bonded with, or her inability, due to the death or abandonment of a parent or carer, to bond with an adult in the first place. In addition, these studies strongly suggest that experiential or sensory deprivation can lead to a lack of physical and cognitive development. ${ }^{13}$ In sum, there is nothing in those studies that vindicates the importance of an emotion for the ability of children to lead good lives. All that children need is to establish a relationship with an attentive caregiver, which means that love is neither necessary nor sufficient for children to thrive.

But is it really necessary to settle this empirical dispute in order to make progress on this question? Liao begins with the assumption that certain goods are in the child's interest and then argues that, as an empirical matter, the emotion of love is necessary for obtaining those goods. Cowden rejects this second claim, and argues that love is not, as an empirical matter, necessary for obtaining the relevant goods. ${ }^{14}$ While I think that these empirical questions are interesting, I believe there is an additional and independent argument for the conclusion that children have a right to be loved. This involves conceiving of the child's good more broadly by appealing to the notion of meaning in childhood. It involves recognizing that well-being is only partly constitutive of the child's good, but it does not exhaust it. Indeed, if I can show that, under normal sociopolitical conditions, love is necessary for meaning in childhood, and that meaning matters a great deal in the lives of children, then I can show that children have a strong interest in being loved, irrespective of the effect that the emotion of love has on a child's well-being. Settling the validity of the studies above then ceases to be necessary for making progress on this question. While it is certainly important to determine the exact ways in which love affects a child's well-being, the important philosophical question is whether love matters for meaning. ${ }^{15}$

\section{Love and Its Value}

Why does love matter in our lives? And more specifically, why does it matter in the lives of children? It is often thought that in order to answer these sorts of question, we need to get a better understanding of what

${ }^{13}$ Cowden (2012) "What's Love Got to Do with It?": 332.

${ }^{14}$ Cowden (2012) "A Need Is Not a Right."

15 I here follow Thomas Christiano in arguing that rights need not be conceptually or metaphysically necessary in protecting human interests in order for them to count as moral or human rights. Indeed, for a right to $\mathrm{X}$ to count as a moral or human right, it suffices that $\mathrm{X}$ is the most reliable way of protecting a basic human interest under normal sociopolitical conditions. See his (2011) "An Instrumental Argument for a Human Right to Democracy," Philosophy \& Public Affairs 39: 142-76. 
love is. Philosophers have turned to this topic by primarily addressing two sets of questions. The first aims at specifying what causes love. Is it someone's personal attributes that make her loveable? Or is it the fact that we find ourselves in relationships that give rise to love? A second set of questions is aimed at explaining what love is. Is love an emotion? A type of moral concern?

I intend to remain agnostic about what causes love. ${ }^{16}$ While it seems possible that some people fall in love because of the personal characteristics of their beloved (wit, intelligence, etc.), it also seems highly plausible that mere relationships give rise to love, as when parents love deeply the newborn who has hardly opened its eyes. ${ }^{17}$ Indeed, love can even come from an unknown source, rendering the lover unable to offer reasons for her feelings. As Harry Frankfurt explains: "The fact that something is important is a circumstance that naturally has its causes, but it may neither originate in, not be at all supported by reasons. It may be simply a brute fact." ${ }_{18}$ In addition to leaving the question of causation open, I also intend to remain largely agnostic on the ways in which love manifests itself. Love may or may not involve warm feelings, or emotions. It may or may not involve a desire for intimacy and affection. It may or may not involve a feeling of well-being. Given the diversity of cultural norms regarding love, and the complexity of human psychology, I want to steer clear of any account that attempts to put or keep love in a box, so to speak.

However, if I am claiming that love plays an important role in the good of children, then I must commit myself to at least one core or common feature of love. That is, there must be something about love, something that is at least partly constitutive of love, that plays a role in our intuitive claims about the right of children to be loved. Is there such a thing? As I see it, there is one fact about love that is very hard to deny namely that those who love are strongly disposed to care a great deal about their beloved (to, as it were, treat their beloved's interests as if they are their own). ${ }^{19}$ Moreover, this expression of concern seems to be present irrespective of the ways in which love comes about and irrespective of the ways in which love manifests itself. It also seems to apply to all modes of love, not only filial love.

Think of romantic love. As we know, an array of actions and emotions are typically associated with romantic love. For example, lovers often feel an urge to display affection toward their beloved, they are often

16 I therefore follow Frankfurt's position on love. See H. G. Frankfurt (1988) The Importance of What We Care About: Philosophical Essays, Cambridge: Cambridge University Press; H. G. Frankfurt (2006) The Reasons of Love, Princeton: Princeton University Press; H. G. Frankfurt (2009) "The Necessity of Love," in A. Voorhoeve, ed., Conversations on Ethics, Oxford: Oxford University Press, pp. 215-32.

${ }^{17}$ For an account that centers on relationships, see N. Kolodny (2003) "Love as Valuing a Relationship," Philosophical Review 112: 135-89.

${ }^{18}$ Frankfurt (2006): 161.

${ }^{19}$ This is also an empirical claim, but one that is quite intuitive and does not rely on the validity of psychological studies of the sort employed by Liao. 
physically attracted to their beloved and they are often disposed to start or maintain a romantic relationship with their beloved. And while these are taken to be the standard manifestations of romantic love, we also know that many lovers are not at all interested in intimacy or the display of affection, and that many are perfectly happy to lead single lives. While we might feel for those who do not surrender to the pleasures of intimacy and affection, we can hardly accuse them of not loving. In these cases, it is plausible to think that their resistance to entering an intimate relationship is linked to a fear of loss, a focus on career or even the desire to allocate all their discretionary time to activities that are by nature solitary. But when it comes to the lack of a disposition for caring, it is much less plausible to think that the agent loves. If she insists that she loves, but is no more attentive to the interests and desires of her beloved than she is to the interests and desires of (say) her local barista, then we might reasonably conclude that she is deluded about her mental life, or else, by her own lights, in love with the barista.

Care also seems to be a necessary ingredient of a loving friendship. Loving a friend involves being more invested in her life than in the lives of colleagues or acquaintances. Again, close friends typically have a strong desire to share activities, spend time together and confide in one another. But although we hold such ideals of friendship, we know all too well that the distractions of modern life coupled with the demands of work and family make it ever so hard to spend quality time with our close friends, to regularly confide in them and sometimes even to stay in touch. But these shortcomings hardly make us question the presence of love. What would certainly make us question the presence of love is a friend's utter disregard for how our life is going, their not showing kindness when we are going through a major life crisis, as when we are gravely ill or going through a separation. Indeed, what we would find unacceptable is the inability or unwillingness of a close friend to care about us.

As it turn outs, philosophers who think differently about what causes love to arise and the ways in which love manifests itself seem to agree that caring is an essential part, or is at least a very large part, of what love is. Philip Pettit says that "for any X and any Y, if they are lovers, then the good of each is a value for the other," ${ }_{20}$ Bennett W. Helm argues that "love just is a distinctive kind of affectionate, identificatory commitment to another: the kind of commitment that emerges from a rational pattern of person-focused emotions," ${ }^{21}$ while Niko Kolodny understands "love exclusively as a state that involves caring about a person." ${ }_{22}$ But of all the authors who have written on this topic, Frankfurt has made caring the most central component of his account. According to Frankfurt, "Loving someone or something essentially means or consists in, among other things

20 P. Pettit (1997) "Love and Its Place in Moral Discourse," in R. E. Lamb, ed., Love Analysed, Oxford: Westview, p. 161.

${ }^{21}$ B. W. Helm (2009) "Love, Identification and the Emotions," American Philosophical Quarterly 46: 52.

${ }^{22}$ Kolodny (2003): 136. 
taking its interests as reasons for acting to serve these interests. Love is itself, for the lover, a source of reasons. It creates the reasons by which his acts of loving concern and devotion are inspired." ${ }_{23}$

Like these authors, I am not claiming that lovers always care about their beloved and always engage in action that is likely to further their ends. It is certainly true that lovers are sometimes busy pursuing their own good, or that frustrating the interests of their beloved is, at times, required by the demands of morality. Love also comes in degrees and lovers sometimes focus on those they love the most. Thus, when I claim that caring is a necessary component of love, I mean something weaker than the claim that wherever there is love there will be robust forms of caring. The claim is simply that those who love are disposed to care much more about the good of their beloved than they would otherwise.

If I am correct that love entails a kind of caring that is somewhat distinct from the caring we display toward those we do not love, then it seems like love is likely to motivate action by putting us in a position in which acting to benefit the object of our love seems all the more urgent, irresistible and compelling. This is because the caring entailed by love is not the caring we display when we wish someone well. It is not even the caring that we express by conforming to the impersonal demands of morality. The caring that comes with love is one of active investment in the lives of those we love. After all, to love someone is to be committed to their good in a similar way in which we are committed to our own good (admitting of degrees of course). And the important implication here is that if $\mathrm{X}$ is disposed to care about Y's good, then $\mathrm{X}$ is disposed to take more costs when pursuing Y's interests or satisfying Y's desires than he would if he were simply conforming to the impersonal demands of morality.

With this thin account of the dispositional core of love in mind, we can now make better sense of why love matters in childhood. Loving parents are disposed to take more costs in order to further the ends of their children. They are disposed to go beyond those who are simply following the reasonable demands of morality. And this matters morally because children are owed much more than what morality can reasonably ask of impartial moral agents: Children are owed the necessary means to lead meaningful lives. Or so I will argue.

\section{Meaning and Why It Matters}

The assumption that a meaningful life matters for children, or that a meaningful life matters for anyone, is not so uncontroversial as it may seem at first glance. Philosophers disagree a great deal over what it means for lives to go well and over the implications that a theory about the good will have for moral thinking and for political life more generally. While I lack the space to engage in detail with this broader philosophical discussion, I will focus on the specific concept of meaning, primarily as it re-

${ }^{23}$ Frankfurt (2006): 37. 
lates to the roles that morality and happiness play in our lives. As a result of this focus, my discussion will be largely in line with Susan Wolf's work on this topic, but with a few minor departures. While Wolf has focused primarily on the activities that confer meaning to adult lives, I will steer the discussion to meaning in childhood while remaining somewhat agnostic about the sorts of activities that make for meaningful adult lives. ${ }^{24}$

So what makes a person's life meaningful? In "Happiness and Meaning: Two Aspects of the Good Life," Wolf defends a hybrid position in which both objective value and subjective attraction come together to endow the lives of persons with meaning. ${ }^{25}$ Meaning, for Wolf, arises when we pursue things that are independently good (the paradigmatic examples being relationships and projects of worth), and when we have pro-attitudes toward them. Her account is based on the idea that neither morality nor happiness can satisfactorily account for the sorts of projects and relationships we typically engage in. ${ }^{26}$ This is because the projects we find worthwhile are at the core of what makes our lives worth living, and so are pursued primarily because we want our lives to matter.

But what does it mean for a project or relationship to be worthwhile? Wolf does not fully specify what makes projects and relationships objectively valuable or good. Instead, she provides us with clear-cut cases in which projects and relationships are either clearly valuable or clearly lacking value. ${ }^{27}$ For the first kind of case, she appeals to her relationship with her young daughter and her investment in academic philosophy. For the second kind of case - namely those that lack value, she points to a person who derives satisfaction from smoking marijuana all day, from doing Sudoku puzzles or from looking after a pet goldfish. The idea is that the second class of activities lacks the sort of objective value that confers meaning to a human life.

Now, I certainly agree with Wolf that there are clear-cut cases on both sides of the spectrum, which confirms the validity of her account. For instance, a career in medicine is objectively valuable while a career in pimping is not. If John loves medicine, he will find meaning by becoming a doctor, but if he decides instead to become a pimp because he derives great pleasure from exercising power over women, this will not be the sort of thing that will bring or add meaning to his life. These sorts of clear-cut cases show that Wolf is pointing to something quite intuitive, which is that subjective attraction to projects of worth endows our lives with meaning.

\footnotetext{
${ }^{24}$ See S. Wolf (1997) "Happiness and Meaning: Two Aspects of the Good Life," Social Philosophy and Policy 14: 207-25; S. Wolf (1997) "Meaning and Morality," Proceedings of the Aristotelian Society 97: 299-315; S. Wolf (2010) Meaning in Life and Why It Matters, Princeton: Princeton University Press.

25 Wolf (1997).

26 Like Wolf, I will use the term happiness to refer to theories that are purely subjective, such as hedonism. I will not treat the concepts of a good life and of a happy life as interchangeable, since I am interested in the question of whether happiness is not only necessary (which strikes me as quite intuitive) but also sufficient for a good life.

27 Ibid.: 209-19, and Wolf (2010): 13-34.
} 
It is important to note that other theorists have reached similar conclusions without appealing to the notion of meaning, and so it is important to recognize that we can hold on to Wolf's insight without engaging in verbal disputes. Frankfurt, for instance, calls attention to the fact that we not only care about things, but we also care about what we care about, and we naturally want to care about things that are worth caring about. ${ }^{28}$ Fred Feldman, who defends a highly sophisticated version of hedonism, argues that the enjoyment of projects that are worthy of enjoyment can in fact increase the value of one's life. ${ }^{29}$ And while these authors will of course disagree about the details of what makes a life go well, agreement exists around the following proposition: There is greater value in a life in which the agent enjoys projects and relationships that are also worthy of her enjoyment.

Despite this area of agreement, there is a real challenge to the accounts that appeal to objective attractiveness, which is that many projects and relationships appear to be located in a fuzzy space of value, as it were. In fact, some of the criticisms leveled at Wolf have appealed precisely to the fact that we just do not know whether a great many things do have objective value after all. ${ }^{30}$ Think of the Sudoku enthusiast. How can we be so confident that testing our minds through games does not have the sort of objective value that makes for worthwhile projects? Or, more troubling even, what makes these games so different from certain subfields within philosophy? Given the fact of grey areas, we should not rule out the possibility that some things have objective value even if they may seem neutral at first glance. The hybrid theorist should therefore give her fellow human beings the benefit of the doubt and accept that some idiosyncratic activities may have objective value after all.

To be sure, the idea of meaning in life might not be very appealing for two kinds of theorists about these issues - namely the champions of happiness and the champions of morality. While the former thinks that pleasure or desire satisfaction does all the work in bringing about good lives, the latter believes that objectively good things are things we should do in order to further the impartial ends of morality (irrespective of whether we happen to be subjectively attracted to them). These views are certainly acceptable alternatives and we do not lose everything by endorsing either one of them. However, these alternatives fail to explain why people often feel compelled to engage in worthwhile projects that are not

${ }^{28}$ Frankfurt (1998): 92-94.

${ }^{29}$ F. Feldman (2002) “The Good Life: A Defense of Attitudinal Hedonism,” Philosophy and Phenomenological Research 65: 619-20.

${ }^{30}$ For her critics, see responses by N. Arpaly and Jonathan Haidt in Wolf (2010): 85-101. The criteria for picking out the projects that can give our lives meaning and those that cannot is an important part of a fully worked out theory about the good. I lack space to engage with this question in detail (I have therefore only focused on clear-cut cases that are highly intuitive) but would suggest that the sort of objective value Wolf is appealing to could be to some extent culturally contingent. I would also suggest that this sort of "contingent" objective value could be tied to activities that a community of valuers finds desirable and praiseworthy (but not necessarily morally required) in a given cultural context. 
very conducive to a life of pleasure. When people have children, pursue a $\mathrm{PhD}$ in philosophy or pursue a career in politics, they choose not to spend their time indulging in purely pleasurable activities. Instead, they choose to engage in projects that are time consuming, exhausting and sometimes even frustrating. They also choose to engage in projects that are not as praiseworthy as what is taken to be morally required. That is, people choose to have their own children or pursue a $\mathrm{PhD}$ when they could be volunteering in an orphanage or working at a local charity. These wellknown facts about human beings should make us skeptical of accounts that equate the good life with a life of pleasure, or with a life of complete servitude to the demands of morality.

It is of course true that some people are content just to feel pleasure, and that they are not too troubled about not engaging with projects of worth. And this seems to create a difficulty. Either pleasure is enough for a good life, in which case the concept of meaning becomes trivial, or meaning is necessary for a good life, in which case it opens the door for perfectionism. Can we avoid each of these implications?

As I understand Wolf, those whose lives lack meaning can still lead perfectly happy lives. What they will not do is succeed in leading good lives, for a good life also requires active engagement with relationships and/or projects of worth. We can therefore avoid the first difficulty: The fact that it is completely up to people to decide whether or not they want to add meaning to their lives does not make meaning trivial. Quite the contrary, it is a wonderful thing if people decide to actively engage with relationships and projects of worth (even if they never think about their lives in those terms). But what about the danger that such an account opens the door to perfectionism?

Those who are wary of the sort of account advocated by Wolf are also concerned with the political implications of biting the bullet on a partially objective account of the good life. ${ }^{31}$ They are concerned that this creates space for an elitist society, in which those who eat fast food are seen as inferior to those who cook healthy food from their garden. Does this give us a reason to reject Wolf's account?

At this stage it might be worth recalling John Rawls' insistence on the value of state neutrality, in which the state owes it to each and every citizen that they are given the space to seek the good in whichever way they deem fit (provided that they respect the right of others to do the same). ${ }^{32}$ Wolf's account only shows that individuals have strong reasons to embrace relationships and projects in which subjective attraction meets objective attractiveness. Nothing about her account conflicts with the requirement that the state should be primarily concerned with respecting persons and their own ideas about what it means for lives to go well.

\footnotetext{
31 See J. Haidt's responses to her work in Wolf (2010): 92-101.

32 J. Rawls (1996) Political Liberalism, New York: Columbia University Press.
} 


\section{Love and Meaning in Childhood}

Let us now think about how children fit with this picture. Can children find meaning in their lives? Or is autonomy and rationality necessary for active engagement with projects of worth? Although Wolf does not say much about children, she has acknowledged in passing that meaning gives "parents a reason to expose their children to a range of worthwhile activities and projects to which they might be 'subjectively attracted' (that is, which they might get passionate about)." 33 As I see it, the same morally significant features of meaning are at play in the lives of children. There are all sorts of activities and relationships that are objectively valuable and that a child will find subjectively attractive. But there are two problems when it comes to children: They are often not yet in a position to identify which projects are worthwhile, and they cannot seek many of these worthwhile projects alone. Let me tackle each of these issues in turn.

Like adults, children are drawn to projects and relationships, irrespective of their objective dimension. But unlike many adults, children, especially the youngest among them, are significantly constrained in their capacity to recognize that certain things have value and that some things lack value. And because of their limited capacity to identify value, children may be just as attracted to playing video games as they are to spending quality time with their siblings. They may be just as interested in counting snails as in learning to play a musical instrument. They may be just as happy to kill ants as to look after their pet dog. But this does not mean that engagement with projects of worth and relationships are morally irrelevant when it comes to children. For the recognition that something is objectively valuable need not take place at the time of engagement. While we can be just as happy in pursuing any of these projects when we are children, as we grow up we come to recognize that our loving relationship with our sibling, our attentive care of our dog and our mastering of a musical instrument conferred meaning on our childhood. That is, we can recognize that our childhood mattered (and for those who never make it to adulthood, others may come to recognize this on our behalf).

We are now in a position to identify one role that those who form loving relationships with children can play in their lives. They can ensure that children engage with relationships and projects of worth, so that there is more to their lives than pleasure and desire satisfaction. To be sure, it is also the role of parents to ensure that children have fun, that they, for instance, go out and about killing ants, counting snails and skipping ropes. But it is also the role of a loving parent to pay special attention to the child's dispositions and talents, to facilitate her engagement with things that will confer meaning on her life - such as working extra hours so that the child can take those piano lessons, or even to spend much of the evening satisfying the child's curiosity through books and

33 Wolf (2010): 118-19. 
stories. ${ }^{34}$ Because of children's limited capacity for autonomy, those who are in loving relationships with them are in a special position to devote the necessary resources, time and attention to ensuring that there is more to their lives than the satisfaction of their bare biological needs.

Of course, another important reason why it matters a great deal that children are part of loving relationships is the relationship itself. For the child, a loving relationship with a parent is a great source of meaning. Even for parents who lack the financial resources, health or discretionary time to help the child engage with projects of worth, the relationship itself confers meaning to the child's life. From the perspective of a child who is otherwise constrained by a limited degree of autonomy, the knowledge that she is loved, that she matters, that she is not alone in the world, endows her life with meaning.

But aren't adults just as dependent on love in order to lead good lives? It is of course true that love can be extremely important in the lives of some adults, especially those who are not subjectively attracted to other projects of worth. But the fact that some adults' good is exhausted by a loving relationship does not mean that adults generally need to be part of a loving relationship in order to pursue the good. With children, the situation is different. Children cannot properly inquire into the nature of the good, nor can they properly seek that which they value. But the fact that children cannot do those things alone hardly shows that they cannot (or need not) do them at all. Like adults, children are curious about the world around them and want to be exposed to aesthetic and cultural experiences. Like adults, children are in search of things to care about, and in search of ends to pursue. Like adults, children's lives can go better or worse, even if they do not suffer from the malaises that follow the lack of stimulation, attention and bonding. But unlike adults, children have very little control over how their lives go. This is why a loving relationship matters so much in the lives of children.

At this stage in the discussion, two objections could be raised against my account. The first is based on an outright rejection of the necessity of meaning in childhood; the second is based on a rejection of the instrumental value of love in ensuring that children find meaning in their lives. I will tackle each of these in turn.

I have already noted that the champions of happiness will have trouble accepting that meaning is a necessary ingredient of a good life. It is possible that they might have even more trouble accepting that meaning is necessary in childhood given children's difficulty in identifying what is objectively attractive. But even though children often struggle to identify objective value, I am inclined to say that meaning matters even more in the lives of children given how little control they have over their lives.

34 Although Adam Swift and Harry Brighouse do not directly address the question of whether children have a right to be loved, some of their discussion on the role of the family in an egalitarian society alludes to the sorts of activities that confer meaning to a child's life. See their (2006) "Parents' Rights and the Value of the Family," Ethics 117(1): 80-108. 
The fact that children are significantly constrained in their ability to identify what is objectively good only shows that they need assistance from adults (in the same way that children's inability to identify education as objectively good only shows that they need to be strongly encouraged to attend school; it does not rebut the necessity of education in their lives). The fact that children often lack the capacity to identify what is good for them hardly counts against there being relationships and projects that endow their lives with meaning.

Now, I do not mean to affirm that meaning exhausts the good for children. Parents need to constantly strike a balance between ensuring that children have fun, that they find meaning and that they acquire the necessary skills to function later on in adulthood. (The fact that children are little hedonistic machines makes it even more important that parents assist them in engaging in relationships and projects of worth. ${ }^{35}$ ) Indeed, by rejecting the importance of meaning in the lives of children, the critic would seem to be committed to the idea that parents can just plug their children into Nozick's experience machine or let them spend all their time playing the latest Nintendo games (especially if those games would also teach children the prudential virtues they will need later in adulthood). And while many of us would respect the right of an autonomous agent to plug himself into Nozick's machine, most of us would be horrified by a world in which children are plugged into the machine until adolescence. Most of us would also be equally terrified by a world in which children are kept their entire childhood in a room with toys so that they can engage in imaginative playing. ${ }^{36}$ Because children cannot autonomously reject engagement with relationships and projects of worth, we best respect them by ensuring that they have access to all the ingredients of a good life, including the ingredients that make for a meaningful childhood.

Let me now respond to the skeptic who contends that, although intimate relationships matter morally, there is no reason to think that adults should be motivated by love when they enter into relationships of this kind. This skeptic would be happy with a world in which governments paid carers in orphanages to enter into similar relationships with children, so long as the relationship played the same intrinsic and instrumental roles that loving relationships do. The objection here is that if it is true that a "commercial" relationship of this sort could bring about happiness and meaning, then there is no reason to think that children need love itself. Instead, what children really need is a guardian throughout their childhood, be they motivated by love or money.

While it is true that a commercial relationship of this sort could play a similar role to a loving relationship, the reason we should resist this

\footnotetext{
35 For a debate on the content of this right, see Feinberg (2003): 124-53, and C. Mills (2003) “A Child's Right to an Open Future?” Journal of Social Philosophy 34: 499-509.

${ }^{36}$ In fact, much of children's imaginative playing revolves around their experiences with their parents. Children often reenact ordinary household activities, dress up like their parents or imagine what their parents are doing at work.
} 
conclusion boils down to the value of reliability. We not only want children to lead meaningful lives, but we also want them to do so reliably. And when carers are motivated by money, the relationship they develop with the child is marked by a certain kind of fungibility. For workers who are paid to enter into relationships with a child, any child with a price tag will do. Indeed, no matter how the state goes about institutionalizing relationships of this sort, there is always the possibility that the carer will become tired of caring for the child, that she will be offered a higher salary in another industry, that she will retire, move to a new town, have her own children, and so on and so forth.

But when relationships are motivated by love, children enjoy it reliably. Those who develop intimate relationships with a child because they are actually motivated by love do not see the child as replaceable and do not see the child as somehow separated from what gives meaning to their own lives. For those who are motivated by love, another child will not do. Moreover, even if loving parents change their career aspirations, life goals and plans, they will continue to advance the good of the child, for their goods become inexorably linked. This means that children who are loved enjoy a loving relationship with an adult in a way that is diachronically and synchronically stable. ${ }^{37}$ They are not significantly vulnerable to losing the relationship over time and over counterfactual worlds. While a paid carer can exit the relationship for all sorts of trivial reasons, a parent who loves will, for instance, stick with a child who has become gravely sick, who has acquired a disability or who needs to move town in order to get special medical treatment. The idea here is that when the glue that keeps the parent and the child together is love, the child is significantly less vulnerable to losing that relationship. The same is not true for arrangements in which adults would be motivated by money or career aspirations. ${ }^{38}$

Before we discuss the question of who has a duty that corresponds to the child's right to be loved, let me summarize what I have argued for so far. Like adults, children have a strong interest in leading meaningful lives. But unlike adults, children are severely constrained in their ability to identify value and to pursue meaningful activities and projects alone. In light of a child's limited capacity for autonomy and rational agency, she has a strong interest to be part of a relationship with an adult who will not only add meaning to her life, but who will also facilitate her engage-

37 The notion of a modally demanding value has been most clearly articulated by P. Pettit in his (2008) "Freedom and Probability: A Comment on Goodin and Jackson," Philosophy \& Public Affairs 36: 206-20, and his (2011) "The Instability of Freedom as NonInterference: The Case of Isaiah Berlin," Ethics 121: 693-716.

${ }^{38}$ Could they be motivated by morality? On one hand, I worry that for someone "eager to help the sick or the poor, any sick or poor person will do," (Frankfurt (2006): 43), but on the other hand, those who are motivated by morality could still love their adopted child. The important point here is that very few people would be able to maintain a loving relationship with a child over time simply based on a desire to follow the demands of morality (no doubt moral saints of this sort exist but they are rare). So even if people are motivated by morality prior to adoption, it is important that they are also disposed to love, for love will ensure that children enjoy the relationship robustly. 
ment with other relationships and projects of worth. This is why love matters so much in the lives of children. Love motivates parents to develop stable and open-ended relationships with children, which in turn endow children's lives with meaning. Because love makes loving relationships diachronically and synchronically stable, children do have a right to be loved after all.

\section{From the Moral to the Political}

Before discussing the political implication of my account, let me offer an analogy to help make better sense of the idea that children have a moral right to be loved, given that love plays a motivational role in my account. When we talk about a human or moral right to vote, it is clear that we are referring to a right that secures an important human interest - namely the interest to participate politically in a democratic society. However, it is not true that voting is strictly necessary for political participation. There are other (actual and conceivable) ways to participate in politics. But even though there are other ways to participate politically, we know that voting does a pretty good job of securing the good of political participation. The same rationale is at play with the right of children to be loved. While it is true that, like adults, children have a strong interest in finding meaning in their lives, it is not true that loving relationships are metaphysically or conceptually necessary for this end. Rather, the idea is that in ordinary sociopolitical circumstances, loving relationships are typically required for children to lead good lives. The upshot here is that, in the same way that there is nothing mysterious about referring to the right to vote, there is also nothing mysterious about referring to the right on the part of children to be loved.

Assuming that it makes sense to talk about a child's right to be loved, does it then follow that parents have a stringent moral duty to feel the emotion of love? According to the skeptic, the answer is no. As Cowden explains: "Loving cannot be a duty because the structure of rights necessitates that there be a real and achievable corresponding duty ... The emotional component of love may be an unachievable duty." ${ }_{39}$ Indeed, if one assumes that stringent moral obligations must be feasible in a strong sense while also accepting that emotions are not sufficiently accessible to us (even though they can at times be cultivated or voluntarily brought about), then one must resist the idea that emotions can be the content of a stringent moral obligation on the part of moral agents. 40

${ }^{39}$ Cowden (2012) “What's Love Got to Do with It?”: 326.

${ }^{40}$ I agree with Liao that the claim that emotions are never commandable is too strong (for a discussion, see S. M. Liao (2006) "The Idea of a Duty to Love," Journal of Value Inquiry 40: 1-22). Still, I believe that moral obligations need to be feasible in a strong sense, and that possibility is distinct from feasibility. But at any rate, we need more empirical evidence regarding the commandability of emotions before we can properly settle the question of whether or not love is sufficiently commandable so as to be the content of a moral obligation on the part of parents. For now, I will assume that love is not suf- 
In anticipating this line of objection, Liao defends the view that the human right of children to be loved gives rise to a duty on the part of parents, who are the primary duty-bearers, to at least try and feel the emotion of love.41 In addition, he claims that the right of children to be loved gives rise to a secondary duty on the part of the state to create the relevant social conditions for children to be loved. ${ }^{42}$ Within this framework, he proposes a number of policies that are meant to facilitate the development of the emotion of love. He cites the importance of flexible working arrangements for parents, generous welfare payments for families with children, parenting education for middle and high schoolers, and more flexible adoption schemes, in which multiple caregivers can share the financial and emotional costs of childrearing. ${ }^{43}$

I certainly agree with Liao that the above policies are important. I also agree that parents should try their best to provide children with the essential conditions for a good life. However, I think that the right of children to be loved actually gives rise to a stringent primary duty on the part of the state and not on the part of parents. The duty in question is not so much to facilitate the development of an emotion, but for the state to do what it legitimately and feasibly can to ensure that children are raised by those who are likely to love them. ${ }^{44}$ In practice, this means that the state must develop and implement parenting and procreation policies geared toward a public ethos in which those who are not subjectively attracted to parenting are much less likely to have children. Instead of leaving it to moral luck, the state has a stringent moral responsibility to do all it legitimately can to ensure that children are raised by parents who really want to enter and maintain loving relationships with them.

But how can the state ensure that children are raised by those who love them, given that it cannot know in advance who is disposed to love, and because of the importance of upholding the rights of adults to bodily integrity and procreation? 45 As I see it, the state can discharge its duty by creating the conditions for parenting to be a genuine voluntary and wellconsidered decision on the part of adults. 46 This entails the removal of the social incentives, barriers and pressures that create a partial mismatch between those who genuinely want to have children and those who end up having them.

ficiently accessible to us so as to ground a stringent moral obligation on the part of parents to love their children.

${ }^{41}$ Liao (2006): 427-30.

42 Ibid.: 430-34.

43 Ibid.: 434-40.

${ }^{44}$ Recall that I endorse a strong notion of feasibility of the sort expressed by the principle of "ought implies can."

45 R. Dworkin (1983) Life's Dominion, New York: Knopf.

${ }^{46} \mathrm{I}$ do not deny that we can be necessitated by contingent facts. For instance, I could become pregnant by accident and come to treasure the life of my fetus. But I am much more likely to be a loving parent either by making a choice to become pregnant, or a choice to carry out an accidental pregnancy even if abortion was a genuine option. 
The first step consists in educating future adults about what parenting truly involves. ${ }^{47}$ Another important step involves making contraception affordable to citizens of all social classes. For those of low income, contraception should be free. The state should also make abortion legal and affordable. I understand that abortion is a morally contentious issue, but the right of children to be part of loving relationships (and the antiorphanage implication of this right) adds a further reason in support of the pro-choice position. The state should certainly not encourage abortion for this would offend against state neutrality, but it should make it available for any person who knows they are unable or unwilling to parent with love.

For those who have made the decision to become parents, Liao is correct in suggesting that the state has an obligation to take work-life balance issues seriously, giving parents more flexibility at work and assistance to those struggling to juggle career and family commitments. ${ }^{48}$ It is also extremely important that the state implements paid parental leave for mothers and fathers so that both sexes have the opportunity to bond with their child at an early time of their life. While feminists have struggled for paid maternity leave in order to increase women's labor participation and bring about gender equality in the workplace, another justification for these schemes lies in their role in protecting the right of children to develop strong loving relationships with both of their parents.

It is of course true that the state will not be able to ensure that all children are born into families in which they will be loved. Even if the state properly implements all the policies above, there will still be adults who will have children and abandon them, or parents who will become unable (due to death or severe kinds of disability) to develop loving relationships with their children. This means that a small number of children will still end up in orphanages and institutions. For those children, the state should make adoption available for both homosexual and heterosexual couples, while also creating programs to encourage the development of loving relationships between adults and children who have not yet been adopted. One interesting program has been recently implemented in parts of Brazil, where local governments encourage individuals to become godparents of children in orphanages. The idea of the program is to bring together children who are unlikely to be adopted (because of age, disease or disability) and adults who are not in a position to adopt them, while absolving the latter from any form of filial responsibility. In order to protect children from abuse, godparents who join the program have to go through security procedures. Godparents are encouraged to host the child on weekends and holidays. However, it is important to remember that while this sort of arrangement can improve the likelihood that children will be part of loving relationships, they should still be seen as a last resort for the state. The lack of a legal bond between child and godparent makes these relationships much less stable and open ended, and so less

${ }^{47}$ Liao (2006): 436.

48 Ibid.: 435-46. 
likely to protect the interest of the child to be part of an ongoing loving relationship.

The list above is obviously not meant to be exhaustive, and much more thinking needs to be put into developing policy ideas that will increase the likelihood that children are born into relationships of love. In this section, I have sought to show that the right of children to be loved gives rise to a stringent responsibility on the part of the state to do all it legitimately can to ensure that procreation is tied to a well-informed desire on the part of persons to become significantly responsible for the good of another human being. Most importantly, this duty is not something to aspire toward, but something that demands real action on the part of the state. Children are not only in danger of abuse and neglect but also in danger of leading lives that are devoid of meaning. As a society, we somehow lowered the standards when we decided that children could be left to their own devices so long as they had their basic needs met, and so long as they were not abused (these standards may serve the needs of pets but certainly not of children). ${ }^{49}$ Children have a strong interest in engaging in relationships and projects that endow their lives with meaning, which gives rise to a stringent obligation on the part of the state to ensure that they are in a position to do so.

\section{Conclusion}

This essay was as much about love as it was about where we want to set the bar when it comes to the lives of children. It is a kind of truism that "Without caring about things our lives would be void of meaning." If we think this truism is correct, it is a mistake to think that the same does not apply to children. Most importantly, it is a mistake to think that fundamental questions about the good only start with the complete development of autonomy. ${ }^{50}$ While children may not yet be in a position to make

49 The idea that children are less developed human beings has been challenged by Alison Gopnik, who argues that children and adults "have very different, though equally complex and powerful, minds, brains, and forms of consciousness, designed to serve different evolutionary functions," in (2009) The Philosophical Baby, New York: Farrar, Straus and Giroux, p. 9.

${ }^{50}$ For some authors, the fact that children lack a sufficient degree of autonomy (and are not yet competent rational agents) shows that they neither have a good to be pursued, nor possess the cognitive resources necessary for its pursuit. As one author puts it, children's "particular interests are unknown to them because they do not yet have a conception of the good, and do not know what their conception of the good will be," in $\mathrm{H}$. Brighouse (2002) "What Rights (if Any) Do Children Have?" in D. Archard and C. M. Macleod, eds., The Moral and Political Status of Children, Oxford: Oxford University Press, p. 43. Indeed, this view is taken to be a truism all throughout the ethical literature on children. For other examples, see J. Coleman (2002) "Answering Susan: Liberalism, Civic Education and the Status of Younger Persons," in D. Archard and C. M. Macleod, eds., The Moral and Political Status of Children, pp. 168-70; J. Feinberg (1980): “A Child's Right to an Open Future," in W. Aiken and H. LaFollette, eds., Whose Child? Parental Rights, Parental Authority and State Power, Totowa, NJ: Littlefield, Adams, and Co., pp. 147-48. 
important life decisions, they still have a right that decisions about their good are coming from a place of love (that those making important decisions on their behalf genuinely care for how their lives go as a whole). I have argued that, apart from being instrumental in ensuring that children are exposed to relationships and projects of worth, loving relationships between parents and children are themselves important sources of meaning. But even though my account makes love central for meaning in childhood, I have avoided talking about a duty to love on the part of individuals. Instead, I have argued that the role of love in maintaining stable relationships between parents and children creates an obligation on the part of the state to ensure that parenting follows a truly voluntary and well-informed decision on the part of its citizens.

Let me now conclude the discussion with a note on the Brazilian case. Was the Tribunal of Justice justified in its handling of Luciane's complaint? Perhaps her father did cause her moral damage in not caring as much about her as he did about his other children (it is a separate question whether parents ought to give all their children the exact same opportunities in life). And perhaps it is true that Luciane was wronged as a result of him not feeling the emotion of love. However, a much more important lesson from the Brazilian case is that Brazil needs to do much more to protect the interest of children to lead good lives qua children. In particular, Brazil needs to legalize abortion and legalize adoption by homosexual couples. It also needs to create a cultural shift in what still is a highly patriarchal society, in which women are heavily pressured into procreation and parenting. Indeed, if Brazilian children are to have their right to be loved protected, the Brazilian government must do much more than blame individuals for not feeling the emotion of love: It must do all it legitimately can to maximize the likelihood that when children are born, they will be part of a stable, loving relationship with an adult. ${ }^{51}$

Luara Ferracioli

University of Amsterdam

Faculty of Social and Behavioural Sciences

1.1.ferracioli@uva.nl

51 I would like to thank Stephanie Collins, Ryan Cox, Fred Feldman, Chris Heathwood, Pablo de Lora, Michael Otsuka, Philip Pettit, Rosa Terlazzo, Alex Voorhoeve and two anonymous referees for this journal for their helpful comments and suggestions. I would also like to thank audiences at the Law Faculty of the Universidad Autonoma de Madrid in 2013, and at the OZSW Conference in Rotterdam in 2013. 